Gender and Human Rights Politics in Japan

Global Norms and Domestic Networks 



\section{Gender and Human Rights Politics}

\section{in Japan}

Global Norms and Domestic Networks

STANFORD UNIVERSITY PRESS 2004 Stanford, California 
Stanford University Press

Stanford, California

(C) 2004 by the Board of Trustees of the

Leland Stanford Junior University

Library of Congress Cataloging-in-Publication Data

Chan-Tiberghien, Jennifer

Gender and human rights politics in Japan : global norms and domestic networks / Jennifer Chan-Tiberghien.

p. cm.

Includes bibliographical references and index.

ISBN 0-8047-5022-X (cloth : alk. paper)

1. Women's rights—Japan. 2. Children's rights—Japan.

3. Human rights advocacy_Japan. I. Title.

HQ1236.5.J3C53 2004

$305.3^{\prime} 0952$ dc22

2004006281

Printed in the United States of America

Original Printing 2004

Last figure below indicates year of this printing:

$\begin{array}{llllllllll}13 & 12 & 11 & 10 & 09 & 08 & 07 & 06 & 05 & 04\end{array}$

Typeset at Stanford University Press in 10/13 Minion 
TO MY MOTHER

- who taught me how to embrace life gracefully-

AND IN MEMORY OF MATSUI YAYORI

-who inspired much of this project. 
